\title{
An update on research on Frankia and actinorhizal plants on the occasion of the 18th meeting of the Frankia-actinorhizal plants symbiosis
}

\author{
Claudine Franche $^{1} \cdot$ Philippe Normand $^{2}$ (D) Katharina Pawlowski $^{3} \cdot$ Louis S. Tisa $^{4}$. \\ Didier Bogusz 1
}

Received: 27 May 2016/Accepted: 30 May 2016 /Published online: 1 July 2016

(C) Springer Science+Business Media Dordrecht 2016

A meeting was held from the 24th to the 27th of August 2015 in Montpellier, France, on Frankia-actinorhizal plants relations. This meeting was the 18th of the series that began in 1978 at Harvard Forest, USA. The initial meeting was sparked by the first isolation of a microbe from a Comptonia peregrina root nodule in pure culture, which had morphological features similar to those of the Frankia symbiont in nodules and was capable of forming nodules on its host (Callaham et al. 1978). This effectively boosted research on the symbiosis. The 2015 meeting was the opportunity to have 80 scientists from 17 different countries, present 34 oral presentations and 51 posters. The object was to exchange ideas on a range of subjects, initiate projects and discuss various controversies. The Montpellier meeting was opened by Jean-Marc Chataîgner, the IRD deputy managing director who outlined the opportunities and challenges facing scientists working on actinorhizal plants. Then there was an invited presentation by Allan Downie, Emeritus fellow at the John Innes Centre, Norwich, UK, who outlined the positive and negative aspects of the actinorhizal symbiosis research in comparison with the Legumes-rhizobia symbiosis.

Philippe Normand

philippe.normand@univ-lyon1.fr

1 Équipe Rhizogenèse, UMR DIADE (IRD-UM2), Institut de Recherche pour le Développement (IRD), 911 avenue Agropolis, BP 64501, 34394 cedex 5 Montpellier, France

2 Université de Lyon, F-69622, Lyon; Université Lyon 1, Villeurbanne; CNRS, UMR5557, Ecologie Microbienne, Villeurbanne; INRA, UMR1418, Villeurbanne, France

3 Department of Ecology, Environment and Plant Sciences, Stockholm University, 10691 Stockholm, Sweden

4 Department of Molecular, Cellular \& Biomedical Sciences, University of New Hampshire, 46 College Road, Durham, NH 03824-2617, USA
Among the various recent developments, that have occurred since the previous meeting held in Shillong, India in 2013, are the cost reduction and ensuing generalization of genome sequencing techniques. Since 2013, there have been 18 genomes published representing all major lineages (Tisa et al. 2016). This mass of data, in turn, permits other "omics" approaches such as transcriptomics (Alloisio et al. 2010; Bickhart and Benson 2011), metabolomics (Brooks and Benson 2016) and proteomics (Mastronunzio and Benson 2010; Udwary et al. 2011) to analyze various physiological aspects.

The resultant databases permit more precise phylogenetic analyses to be performed.

A study has been completed on the conserved genomic core proteins within actinobacteria and this positioned Frankia at the root of aerobic actinobacteria (Sen et al. 2014). The datasets can also be used to generate and characterize mutants (Kakoi et al. 2014), identify cytosine methylations (Kucho and Kamiharai 2016), or follow the expression of genes involved in a given function such as the hup genes coding for hydrogenase (Richau et al. 2013). Metabolic profiling has also been undertaken to discern how PAS domains have evolved (Sarkar et al. 2016) or to compare globally metabolic machineries (Thakur and Sen 2016).

Besides Frankia, other bacteria have been isolated from actinorhizal nodules and sequencing them has become a convenient approach to gain knowledge on their function and physiology (Bose et al. 2016; Ghodhbane-Gtari et al. 2014).

A review of stress-responses in Frankia has shown the extent of its physiological adaptability (Ngom et al. 2016a). Most Frankia lineages have a representative that was isolated many years ago. The exception is cluster2, that resisted numerous isolation attempts and for which a representative genome was determined (Persson et al. 2015). However last year, this obstacle was overcome using an approach combining massive direct phenotypic characterization and growth medium fine tuning (Gtari et al. 2015). 


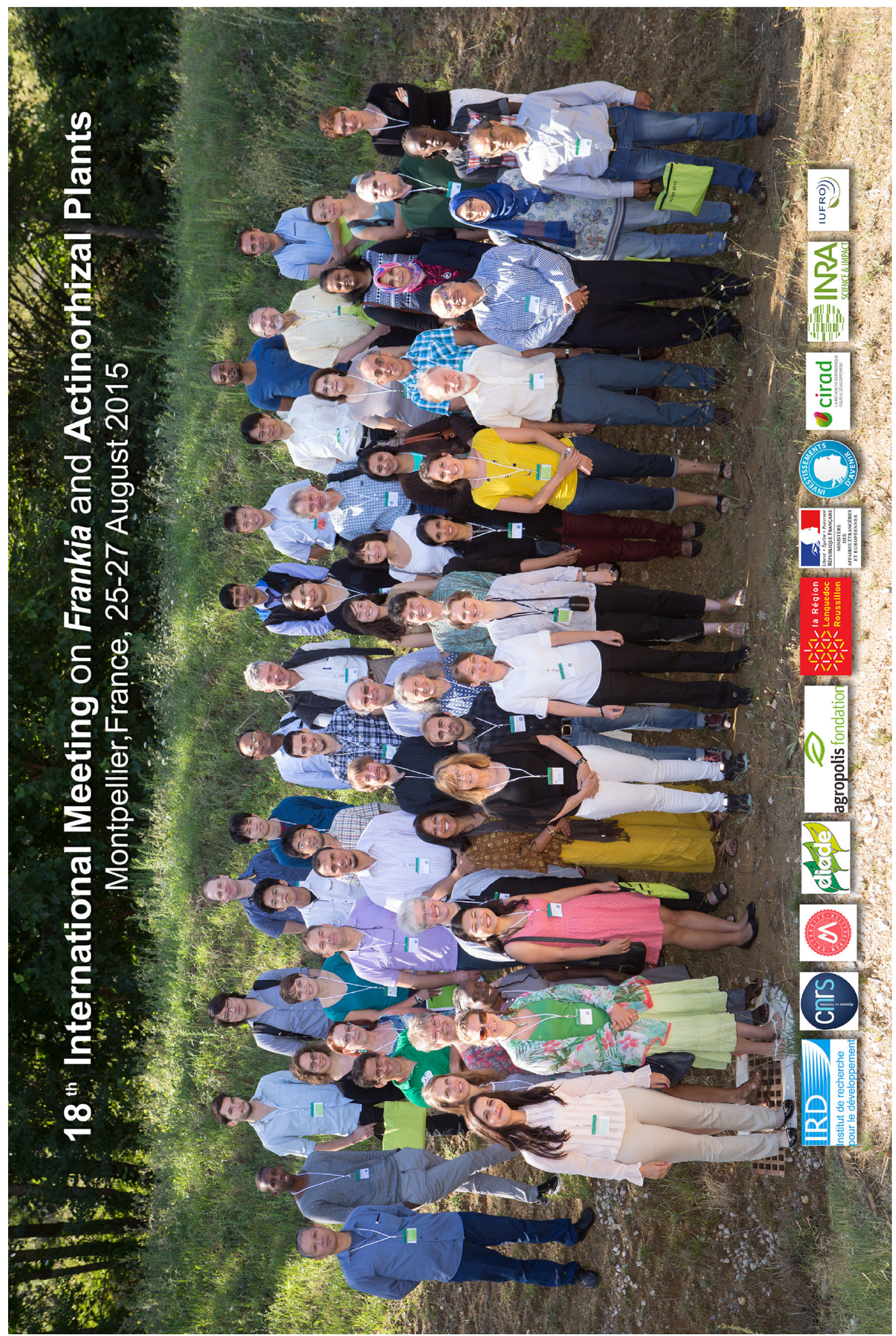


On the plant-side, the sequencing of the first genomes for the actinorhizal plants, Casuarina glauca and Datisca glomerata, was announced and will be initiated. Other approaches based on ESTs and transcriptomics were also reported (Hocher et al. 2011; Demina et al. 2013; Diedhiou et al. 2014). In addition, metabolomics have been used to analyse globally nitrogen and carbon metabolism in (Carro et al. 2016a) and in Datisca (Persson et al. 2016).

Signalling between partners in particular was much discussed. Transgenic $C$. glauca expressing a transcriptional fusion between the promoter from the Nodule Inception (NIN) gene and the GFP reporter gene was used to develop a bioassay for the purification of the biologically active molecules in the supernatant of Frankia sp. CcI3 (Chabaud et al. 2016). This confirmed a previous study on a factor from Frankia ACoN24d (Ceremonie et al. 1999). Interestingly, such diffusible active molecules were found to induce calcium spiking in C. glauca (Chabaud et al. 2016) and in A. glutinosa (Granqvist et al. 2015). The existence of defense peptides in several lineages was also discussed as well as their effects on symbiotic Frankia (Carro et al. 2015; Carro et al. 2016b). The role of auxins and auxin transporters was studied (Imanishi et al. 2014) and a gene coding for a chitinase was investigated (Graça et al. 2016).

The phytometabolomic fingerprinting of consumed actinorhizal plants permitted the identification of a large diversity of the compounds present (Kar et al. 2016). Other focused studies also permitted the screen of molecules found in actinorhizal leaves and fruits of Myrica nagi that have analgesic, cyclooxygenase inhibiting (Middha et al. 2016b) or antiinflammatory properties (Middha et al. 2016a).

The ecology of actinorhizal plants was another topic and information was presented on these plants and their associated microbes. Besides the global contribution of filaos for the rehabilitation of poor sites in various areas of the world such as China and India (Zhang et al. 2016) and of alder for the same purpose in Canada (Callender et al. 2016), a major focus is the search for salinity-resistant casuarina lineages (Ribeiro-Barros et al. 2016). The underlying mechanisms are also being studied (Mansour et al. 2016; Selvakesavan et al. 2016). As pioneer species, actinorhizal plants are exposed to a wide array of stresses (Ngom et al. 2016b) which have been reviewed along with approches to transform Casuarina genetically (Froussart et al. 2016). The ecology and diversity of strains and Morella hosts in South Africa (Wilcox and Cowan 2016) or Betulaceae hosts in North America (Samant et al. 2016) and Europe (Cotin-Galvan et al. 2016) have been studied in relation to soils. The impact of climate change on alder has also been examined (Tobita et al. 2016).

The participants at the meeting had the opportunity to visit an Agroforestry site managed by INRA colleagues in Restinclières where trees (mostly high-return walnuts, and black alders) are grown in association with cereal crops (Cardinael et al. 2015). This excursion was followed by a visit to the medieval village of St-Guilhem-le-Désert.
The next meeting dealing with the Frankia-actinorhizal plants symbiosis is scheduled for 2017 and will be held in Hammamet, Tunisia.

Acknowledgments We acknowledge the receipt of grants from the Institute of Research for Development (IRD), the Centre National de la Recherche Scientifique (CNRS), the University of Montpellier (UM), the French Ministry of Foreign and European Affairs, the Conseil Régional Languedoc-Roussillon and the Agropolis Foundation for the organization of the 18th Frankia and actinorhizal plants meeting.

\section{References}

Alloisio N, Queiroux C, Fournier P, Pujic P, Normand P, Vallenet D, Medigue C, Yamaura M, Kakoi K, Kucho K (2010) The Frankia alni symbiotic transcriptome. Mol Plant-Microbe Interact 23:593-607

Bickhart DM, Benson DR (2011) Transcriptomes of Frankia sp. strain $\mathrm{CcI} 3$ in growth transitions. BMC Microbiol 11:192

Bose D, Sarkar I, Labar R, Oshone R, Ghazal S, Morris K, Abebe-Akele F, Kelley Thomas W, Tisa LS, Sen A (2016) Comparative genomics of Prauserella sp. Am3, an actinobacterium isolated from root nodules of Alnus nepalensis in India. Symbiosis 70:49-58

Brooks JM, Benson DR (2016) Comparative metabolomics of root nodules infected with Frankia sp. strains and uninfected roots from Alnus glutinosa and Casuarina cunninghamiana reflects physiological integration. Symbiosis 70:87-96

Callaham D, Del Tredici P, Torrey JG (1978) Isolation and cultivation in vitro of the actinomycete causing root nodulation in Comptonia. Science 199:899-902

Callender KL, Roy S, Khasa DP, Whyte LG, Greer CW (2016) Actinorhizal alder phytostabilization alters microbial community dynamics in gold mine waste rock from Northern Quebec: a greenhouse study. PLoS One 11:e0150181

Cardinael R, Chevallier T, Barthes BG, Saby NPA, Parent T, Dupraz C, Bernoux M, Chenu C (2015) Impact of alley cropping agroforestry on stocks, forms and spatial distribution of soil organic carbon - a case study in a Mediterranean context. Geoderma 259:288-299

Carro L, Pujic P, Alloisio N, Fournier P, Boubakri H, Hay AE, Poly F, Francois P, Hocher V, Mergaert P, Balmand S, Rey M, Heddi A, Normand P (2015) Alnus peptides modify membrane porosity and induce the release of nitrogen-rich metabolites from nitrogen-fixing Frankia. The ISME journal 9:1723-1733

Carro L, Persson T, Pujic P, Alloisio N, Fournier P, Boubakri H, Pawlowski K, Normand P (2016a) Organic acids metabolism in Frankia alni. Symbiosis 70:37-48

Carro L, Pujic P, Alloisio N, Fournier P, Boubakri H, Poly F, Rey M, Heddi A, Normand P (2016b) Physiological effects of major upregulated Alnus glutinosa peptides on Frankia sp. ACN14a. Microbiology. doi:10.1099/mic.0.000291

Ceremonie H, Debelle F, Fernandez MP (1999) Structural and functional comparison of Frankia root hair deforming factor and rhizobia nod factor. Can J Bot 77:1293-1301

Chabaud M, Gherbi H, Pirolles E, Vaissayre V, Fournier J, Moukouanga D, Franche C, Bogusz D, Tisa LS, Barker DG, Svistoonoff S (2016) Chitinase-resistant hydrophilic symbiotic factors secreted by Frankia activate both $\mathrm{Ca}(2+)$ spiking and NIN gene expression in the actinorhizal plant Casuarina glauca. New Phytol 209:86-93

Cotin-Galvan L, Pozzi AC, Schwob G, Fournier P, Fernandez MP, Herrera-Belaroussi A (2016) In-planta sporulation capacity enhances infectivity and rhizospheric competitiveness of Frankia strains. Microbes Environ 31:11-18

Demina IV, Persson T, Santos P, Plaszczyca M, Pawlowski K (2013) Comparison of the nodule vs. root transcriptome of the actinorhizal 
plant Datisca glomerata: actinorhizal nodules contain a specific class of defensins. PLoS One 8:e72442

Diedhiou I, Tromas A, Cissoko M, Gray K, Parizot B, Crabos A, Alloisio N, Fournier P, Carro L, Svistoonoff S, Gherbi H, Hocher V, Diouf D, Laplaze L, Champion A (2014) Identification of potential transcriptional regulators of actinorhizal symbioses in Casuarina glauca and Alnus glutinosa. BMC Plant Biol 14:342

Froussart E, Zhong C, Jiang Q, Bonneau J, Bogusz D, Franche C (2016) Biotechnological strategies for studying actinorhizal symbiosis in Casuarinaceae: transgenesis and beyond. Symbiosis 70:101-109

Ghodhbane-Gtari F, Nouioui I, Salem K, Ktari A, Montero-Calasanz Mdel C, Tisa LS, Klenk HP, Gtari M (2014) Nocardia casuarinae sp. nov., an actinobacterial endophyte isolated from root nodules of Casuarina glauca. Antonie Van Leeuwenhoek 105:1099-1106

Graça I, Liang J, Guilherme M, Tavares P, Ferreira-Pinto MM, Melo AMP, Ribeiro-Barros AI, Pereira AS (2016) Cloning, overexpression and functional characterization of a class III chitinase from Casuarina glauca nodules. Symbiosis 70:139-148

Granqvist E, Sun J, Op den Camp R, Pujic P, Hill L, Normand P, Morris RJ, Downie JA, Geurts R, Oldroyd GE (2015) Bacterial-induced calcium oscillations are common to nitrogen-fixing associations of nodulating legumes and nonlegumes. New Phytol 207:551-558

Gtari M, Ghodhbane-Gtari F, Nouioui I, Ktari A, Hezbri K, Mimouni W, Sbissi I, Ayari A, Yamanaka T, Normand P, Tisa LS, Boudabous A (2015) Cultivating the uncultured: growing the recalcitrant cluster-2 Frankia strains. Nature Sci Rep 5:13112

Hocher V, Alloisio N, Auguy F, Fournier P, Doumas P, Pujic P, Gherbi H, Queiroux C, Da Silva C, Wincker P, Normand P, Bogusz D. (2011) Transcriptomics of actinorhizal symbioses reveals homologs of the whole common symbiotic signaling cascade. Plant Physiol 156: 700-711

Imanishi L, Perrine-Walker FM, Ndour A, Vayssieres A, Conejero G, Lucas M, Champion A, Laplaze L, Wall L, Svistoonoff S (2014) Role of auxin during intercellular infection of Discaria trinervis by Frankia. Frontiers Plant Sci 5:399

Kakoi K, Yamaura M, Kamiharai T, Tamari D, Abe M, Uchiumi T, Kucho K (2014) Isolation of mutants of the nitrogen-fixing actinomycete Frankia. Microbes Environ 29:31-37

Kar P, Dey P, Misra AK, Chaudhuri TK, Sen A (2016) Phytometabolomic fingerprinting of selected actinorhizal fruits popularly consumed in North-East India. Symbiosis 70:159-168

Kucho K-i, Kamiharai T (2016) Comprehensive identification of 5methylcytosines in Frankia genomes. Symbiosis 70:31-36

Mansour SR, Abdel-lateif K, Bogusz D, Franche C (2016) Influence of salt stress on inoculated Casuarina glauca seedlings. Symbiosis 70: $129-138$

Mastronunzio JE, Benson DR (2010) Wild nodules can be broken: proteomics of Frankia in field-collected root nodules. Symbiosis 50: $13-26$

Middha SK, Usha T, Babu D, Misra AK, Lokesh P, Goyal AK (2016a) Evaluation of antioxidative, analgesic and anti-inflammatory activities of methanolic extract of Myrica nagi leaves - an animal model approach. Symbiosis 70:179-184

Middha SK, Goyal AK, Bhardwaj A, Kamal R, Lokesh P, Prashanth HP, Wadhwa W, Usha T (2016b) In silico exploration of cyclooxygenase inhibitory activity of natural compounds found in Myrica nagi using GC-MS. Symbiosis 70:169-178

Ngom M, Diagne N, Laplaze L, Champion A, Sy MO (2016a) Symbiotic ability of diverse Frankia strains on Casuarina glauca plants in hydroponic conditions. Symbiosis 70:79-86

Ngom M, Oshone R, Diagne N, Cissoko M, Svistoonoff S, Tisa LS, Laplaze L, Sy MO, Champion A (2016b) Tolerance to environmental stress by the nitrogen-fixing actinobacterium Frankia and its role in actinorhizal plants adaptation. Symbiosis 70:17-29

Persson T, Battenberg K, Demina IV, Vigil-Stenman T, Vanden Heuvel B, Pujic P, Facciotti MT, Wilbanks EG, O'Brien A, Fournier P, Cruz
Hernandez MA, Mendoza Herrera A, Medigue C, Normand P, Pawlowski K, Berry AM (2015) Candidatus Frankia Datiscae $\mathrm{Dg} 1$, the actinobacterial microsymbiont of Datisca glomerata, expresses the canonical nod genes nodABC in Symbiosis with its host plant. PLoS One 10:e0127630

Persson T, Van Nguyen T, Alloisio N, Pujic P, Berry AM, Normand P, Pawlowski K (2016) The N-metabolites of roots and actinorhizal nodules from Alnus glutinosa and Datisca glomerata: can D. glomerata change $\mathrm{N}$-transport forms when nodulated? Symbiosis 70:149-157

Ribeiro-Barros AI, da Costa M, Duro N, Graça I, Batista-Santos P, Jorge TF, Lidon FC, Pawlowski K, António C, Ramalho JC (2016) An integrated approach to understand the mechanisms underlying salt stress tolerance in Casuarina glauca and its relation with nitrogenfixing Frankia Thr. Symbiosis 70:111-116

Richau KH, Kudahettige RL, Pujic P, Kudahettige NP, Sellstedt A (2013) Structural and gene expression analyses of uptake hydrogenases and other proteins involved in nitrogenase protection in Frankia. J Biosci 38:703-712

Samant S, Huo T, Dawson JO, Hahn D (2016) Abundance and relative distribution of Frankia host infection groups under actinorhizal Alnus glutinosa and non-actinorhizal Betula nigra trees. Microb Ecol 71:473-481

Sarkar I, Normand P, Tisa LS, Gtari M, Bothra A, Sen A (2016) Characterization of PAS domains in Frankia and selected actinobacteria and their possible interaction with other co-domains for environmental adaptation. Symbiosis 70:69-78

Selvakesavan RK, Nair DN, Thushara P, Abraham SM, Jayaraj RSC, Balasubramanian A, Deeparaj B, Sudha S, K. S. Sowmiya Rani, Bachpai VKW, Ganesh D, Diagne N, Laplaze L, Gherbi H, Svistoonoff S, Hocher V, Franche C, Bogusz D, Nambiar-Veetil M (2016) Intraspecies variation in sodium partitioning, potassium and proline accumulation under salt stress in Casuarina equisetifolia Forst. Symbiosis 70:117-127

Sen A, Daubin V, Abrouk D, Gifford I, Berry AM, Normand P (2014) Phylogeny of the class actinobacteria revisited in the light of complete genomes. The orders 'Frankiales' and Micrococcales should be split into coherent entities: proposal of Frankiales ord. nov., Geodermatophilales ord. nov., Acidothermales ord. nov. and Nakamurellales ord. nov. Int J Syst Evol Microbiol 64:3821-3832

Thakur S, Sen A (2016) Comparative analysis of metabolic machinery of Frankia along with other selected actinobacteria. Symbiosis 70:59-68

Tisa LS, Oshone R, Sarkar I, Ktari A, Sen A, Gtari M (2016) Genomic approaches toward understanding the actinorhizal symbiosis: an update on the status of Frankia genomes. Symbiosis 70:5-16

Tobita H, Yazaki K, Harayama H, Kitao M (2016) Responses of symbiotic N2 fixation in Alnus species to the projected elevated $\mathrm{CO} 2$ environment. Trees Struc Func 30:523-537

Udwary DW, Gontang EA, Jones AC, Jones CS, Schultz AW, Winter JM, Yang JY, Beauchemin N, Capson TL, Clark BR, Esquenazi E, Eustaquio AS, Freel K, Gerwick L, Gerwick WH, Gonzalez D, Liu WT, Malloy KL, Maloney KN, Nett M, Nunnery JK, Penn K, Prieto-Davo A, Simmons TL, Weitz S, Wilson MC, Tisa LS, Dorrestein PC, Moore BS (2011) Significant natural product biosynthetic potential of actinorhizal symbionts of the genus Frankia, as revealed by comparative genomic and proteomic analyses. Appl Environ Microbiol 77:3617-3625

Wilcox D, Cowan D (2016) Diversity of Frankia in root nodules of six Morella sp. from the cape flora of South Africa. Plant \& Soil 400: 123-132

Zhang Y, Zhong CL, Han Q, Jiang QB, Chen Y, Chen Z, Pinyopusarerk K, Bush D (2016) Reproductive biology and breeding system in Casuarina equisetifolia (Casuarinaceae) - implication for genetic improvement. Austr J Bot 64:120-128 